\title{
Impact of International Business on Kosovos Economic Development with Emphasis on Tourism
}

\author{
Fatos Ukaj \\ Public University"Hasan Prishtina" in Prishtina,Kosovo \\ Email: fatos_ukaj@yahoo.com
}

Doi:10.5901/mjss.2015.v6n3s2p35

\begin{abstract}
Most activities in the tourist development direction, through international business activities, have as result environmental changes and have economic impacts. This paper investigates the contribution of the International Business developments on Tourism in Kosovo, in terms of the country's tourism environment and implications on sustainability, based on the use and preservation of available resources. The result of the analyses shows the link between domestic resources utilizations and foreign direct investment that will result with economic growth and sustainable development. The practice and evidences analyzed lead us to the need for development of the plans on future engagements in country's tourism, expecting growth of FDI in tourism as well as raising the issue of environment preservation.
\end{abstract}

Keywords: international business, tourism, environment, sustainable development, resources.

\section{Introduction}

Tourism is known and considered as one of the important economic activities in Kosovo and the Western Balkans Region in general, and it should be treated accordingly with changes in environment. These changes are a result of the globalization impact and the requirements of visitors (tourists). Development in tourism is definitively associated with integral developments of a local economy, counting that tourism as well, will help in the achievement of the country's sustainable economic development. The objective of the paper is to analyze the factors affecting the development of Tourism in Kosovo using approach based on the principles of the international business respectively its rules and standards. Through identification of a problem, evaluating and explaining the contexts and the linkage between Tourism and International Business as important factors, as a result of this paper it shows that Kosovo was not increasing attraction for the Foreign Direct Investments at all and particularly in tourism. In the conclusions of the paper, the proposal for a modern approach to tourism development is presented. This approach will be based on the market laws and active support by the government, businesses and tourist organizations in country. It has been observed that likewise in the countries of the region, the tourism has a positive movement due to government's tourism development support. The tourism importance itself, as one of the country's economic development levers, has brought a strategic orientation of finding investors, thus paying special attention to tourism, as an important and strategic sector. International business is a determinant of the possibilities that a country attracts investors and businesses to drive their investments in certain destination. International Business includes all business operations that are conducted between companies of two or more countries. [Daniels et all 2004, Kukaj 2014, Llaci 2006]. International tourism is considered as a significant strategic factor for economic growth (Sinclair and Stabler, 2002]. According to the Samimi et al.[ 2011] the International tourism would contribute to an income increase in two additional ways at least: first, enhancing efficiency through increased competition among firms and other international tourist destinations (Krueger, 1980) ; second, facilitating the exploitation of economies of scale in local firms (Helpman and Krugman, 1985). In regard to the role of Foreign direct investments in development of tourism there were few empirical studies performed, and they are references for importance of the problem trying to prove the causality between FDI and Tourism [More and Craigwell 2011; Samimi et all 2013; Sanford and Dong 2000; Tisdell and Wein 1991]. Using different statistical methods and analyzing findings authors find positive and significant impact of FDI in tourism development. In the past authors assumed that there is one way impact from tourism to FDI, meaning that tourism potential of the country will attract FDI. In support of this linkage the Sanford and Dong [2000] stated that international tourism gives potential investors the opportunity to obtain first-hand knowledge of the environment of the country being visited and, as a result, investment possibilities could be identified. We will try using descriptive approach to identify, evaluate and analyze the factors that influence on the relation of Tourism to FDI and 
inversely. In this manner we will assess the business environment for investing in tourism of a country? What legal infrastructure do we have in order that the investors can carry out their mission, and also achieve economic effects? Do we care to preserve the environment and have a modern approach towards ecology? An expectation from this paper is how to find a modern approach to tourism development, which will be based on the market laws. Such an approach requires that those who have supervision over the tourism industry and its development, they can do so by applying the best European and world practices, performing management activities based on planning, organization, and their control. Here, there is room for application of an adequate marketing strategy combined with interdisciplinary methods that will be able to be adapted, depending on the environmental changes and economic situation. Which marketing mix can give maximum effect in the country's attractiveness for foreign investments?. Recognizing the relationship of the tourism and International business will have significant effects for development of different policies for stimulating investments and tourism marketing of a country.

\section{Environmental and Tourism Priority Issues}

The economic development of a country such as Kosovo is, usually linked to various fields of the industries, and one of them is tourism, refered to as "sustainable tourism", one that is based on the resources, caring of resources, heritage of a country, ecology, and the success on the market. The achieved globalization level makes visible the need for integrations and economic cooperation in the Balkans region as well, including tourism as a promising industry. The international business development had an increase in the past period and tourism is part of this international economic exchange. Based on the data from WTO(World Tourism Organization) in the world level, the tourism data for the year 2013 has a participation of 9\% of GDP (direct, indirect impact ), that is, in each 11 employees one is in tourism, the participation of $6 \%$ in the world's export, 1.035 million tourists in 2012, while local tourists are estimated to be 5-6 billions. According to the Kosovo Statistical Office data in 2013 we had 50,074 foreign visitors (officially registered) that is, an increase of 2, $63 \%$ compared to 2012 where there were 48,790 foreign visitors. While if we compare 2013 with the $2011^{\text {th }}$, we see an increase by $64.99 \%$ compared to 2011 when there has been 30.349 foreign visitors. In tourism precisely, business impacts occur mostly, either in the economic or in the ecological and social aspect, by all means. A tourist who comes to Kosovo to visit for e.g. the country's historical-cultural heritage, has additional or secondary needs, that is, needs for accommodation, restaurants, transport, shopping, which automatically increases the need to increase economic activities related to tourism development. On the other hand, the tourist requirements have to do with the use of certain resources which, from over-exploitation may have an impact on the life environment and nature because it is evident that this would create a quantity of wastes to which it should be paid attention. The work in tourism, however, requires educated people with broad knowledge, which in contact with foreign tourists can meet their demands and needs. Moreover, it can be seen the social impact on the country through employment, education and care for environment. Therefore, we are faced with a chain, which up to tourism development, shows us whether we have a good tourism offer, sufficient investments, institutional support and human and material resources. On the other hand the tourism development, directly or indirectly impacts the economic development of the country-region, more spending of resources(water, energy, etc.), damaging of flora and fauna, environmental pollution (wastes, vehicles ), the impact of tourists on the style and life of locals (changing of moral, culture norms, etc.). The degree of importance of these issues in Kosovo and in the region is not at desired level, it turns out that, for side effects there's no strategy. Apart from the economic aspect of tourism development, it should be paid attention to the impacts of this phenomenon on the country's environment and surroundings. If we have tourism and economic development in general, then the goal should be to have a "Sustainable development". Sustainable development is a development that meets present needs without compromising the ability of future generations to meet their needs. It contains within itself two key concepts: The concept of "needs", in particular the essential needs in poor countries, to which priority should be given; and the idea of imposed limitations by the state of technology and social system on the environment's ability to meet current and those future needs.[WCED 1987]. A sustainable tourism development should be each country's objective, and this would be achieved if the profit desire would be harmonized, resources preserved, specific features such as culture and tradition, waste management, care towards nature, etc. A country's sustainable economic development is achieved by cooperation on the level of state institutions and economic subjects, but in fact this cooperation should be based on its three components, and those are the country's economy, ecology and society. These three sustainable development dimensions are in constant mutual interaction completing each other. (Ebner,D. \& Baumgartner,R.J 2006). At the international level, since the 90s (Rio Declaration 1992), it has been made clear that we shall pay attention to the tourism development impact on the environment, and why this has become an international issue, because the environmental impact is not felt only in the countries of tourist destinations but also in other countries of the region and beyond. So, positive impact is directly noticed through development and 
welfare improvement in tourist destinations and the countries in which it has an effect, however, a negative impact is noticed through usage of resources, pollution, even in other countries. How much attention is paid to these issues remains the responsibility of state institutions that should be engaged in the creation of environmental protection policies. The role of economic subjects isn't anymore unimportant that, besides economic benefits, they express their readiness and willingness to deal more seriously with environmental issues. No one denies the need to have economic business accounts positive, but, they should put emphasis on that they should be aware that in addition to their identifiable expenses, either monetary or material, it should be taken into account the resources non-monetary expenses, left in your disposal in order to achieve the satisfaction of tourists and meet their needs.

\section{International Business}

Sustainable Tourism development is related to the resources and their usage, moreover this concerns also the businesses on this field which must be familiar with, and operate based on the principles of the international business respectively its rules and standards. Economic development, a local institutional imperative, has to do with tourism, which can be a pillar of a national economy. The globalization level has made it possible and necessary that, the development impact in the tourism field in the countries of the region and beyond, to encourage local entrepreneurs to invest in capacities, mainly hotels and accompanying services. All this development is going in the direction of improving the supply, quality and care for visitors, by application of a marketing that remains desirable. Development in this globalization means also the adaptation and harmonization with the European and world tourism standards which requires a different management, application of the marketing concept. Whereas the transfer of knowledge is essential due to the intersectoral cooperation, it is important for the country's economy, in order to use novelty from different countries of the world, and skills of local experts in the tourism field. In the creation of a touristic offer, we should be concentrated on the wealth, cultural and historical heritage, which may be incorporated with an offer of complementary resources of the countries in the Balkans. This should be seen as a possibility, and not as an obstacle, because with a good adjustment, the tourists while visiting a country in the region can also be interested in the Kosovo's offer. In the current situation a tourism definition makes it an organized activity that at this time creates a capital which could be a decisive factor in the future local economy development, in the function of the tourism development as well as other branches of economy, culture, sport, etc. Kosovo should be integrated into the regional developments and initiatives, which will make Kosovos tourist offers a part of tourist packages for the visitors from the whole world. Globalization is a fact that has affected us as well, and it can be seen from the visitors' interest from Japan, Europe, etc., to spend few days in Kosovo, after having visited any other country of the Balkans. The lack of touristic resources such as a sea or lakes, can be compensated with mountains, cultural and historical heritage. This makes regional integration and cooperation necessary and inevitable. Afterwards, with little invention and investment, the involvment of the world tour operators will take place, in bringing visitors from entire world. Prognoses of "Touristic vision 2020" of the World Tourist Organization [WTO] predict that international visits in the world level will reach 1,56 billion by 2020 , or it will be realized a turnover approximately of 2 billion US dollars, which itself shows the growth of tourism branch in the world level. The important thing is to be identified the route through which tourists reach the touristic destination, overall characteristics of the countries differ, and Kosovo in contrast to countries in the region has alternative of the road and air traffic by which the tourists and visitors arrive. From the experiences of other countries as a way of reaching the tourists destination according to the WTO we note and distinguish that: by "air"arrived $52 \%$, by "roads" $40 \%$ of arrivals, $6 \%$ through "water road", and by "train" $2 \%$ of the number of visitors.

\section{Investment Characteristics and Organization in Tourism}

Foreign direct investments or FDI (Foreign Direct Investment) are necessary, welcomed and important for Kosovo but also for the regional countries such as Albania and Montenegro, they would be as an economy infusion in general, but also for tourism as a potential, on which are counting these countries and their economies. Foreign direct investments FDI have been defined as cross-border investment, by non resident economic unit with an objective of taking a sustainable interest in a resident enterprise of another economy.[OECD 2013]. Investments in tourism are important because of the fact that they are investments which on the greatest part of the fresh capital remain within the hosting country, mainly as a capital, technology, and know-how. Foreign direct investments in Kosovo in 2012 were 232 million Euros, which is, for $41,2 \%$ less than in 2011 , which is, 5\% of GDP being a noticeable deterioration.[CBK 2012]. So fare the curent way of managing foreign investments there's no space for praiseworothy, excluding Montenegro, where the majority of tourism investments is done by foreigners, this trend both in Kosovo and Albania should take another 
direction, and became attractive for foreign investors. The capacity of local investors is small and limited, while large foreign investors have not yet decided to enter in this region, first of all because of the lack of information, political-legal circumstances, financial crisis, etc. Serious investments by sizable investors will bring substantial capital with them, and just because of this in the game will be lot of money and long-term major projects. The region countries haven't managed to communicate with the stakeholders and to persuade them on the opportunities, resources, legislation, investment safety and other advantages compared to the competition (other countries), which it should be pointed out, in a broad neigberhood as it is Croatia, Cyprus, and Greece. It doesn't stand the fact that there has been no interest by big investors, but the response of governments was sluggish and not insistent on providing support, and for this reason many of them hesitated and withdrew from the idea to invest. Precisely, the phase when the investors' interest is expressed in these countries is problematic, because the bureaucracy slows down and complicates every step of the process, but also it blurs things, which makes the investor to lose patience and faith in the country where he wants to invest his capital. Actually, here it is necessary a communication based on the marketing mixed concept, making it necessary for the process that carry through investments: from tourist enterprises, a particular towns, and tourist destination in general. It has to be computerized and automated, thus it becomes attractive for investors and easy to investment, since they will have enough information on the conditions, most favorable time, and commitment that await. Today, definitively, the speed in the worlds economy, as well as, the right moment are the factors that determine the development opportunity of a country, and if the countries of the region such as Kosovo, Albania and Montenegro don't adapt their economies to a such pace, that is, to keep up step with the world, then the others in the closer and far circle, as well, with take the opportunity, thus leaving the economy and tourism of these countries at the low development level and unattractive to investors, and this certainly isn't in the interest of anyone including governments of respective countries. In foreign direct investments, we distinguish two dominant modes of investment, which are Foreign Direct Horizontal Investments and Foreign Direct Vertical Investments [GDWH 2011]. Foreign Direct Horizontal Investments in fact are those when it's invested in the same fields in another country, in this case it would be tourist enterprises of the region and beyond to invest in the field of tourism in our countries. This represent possibility to invest in the existing capacities in the country of investment, by improving and expanding capacities, or starting with entirely new projects from the beginning. In Montenegro and Croatia there are some examples where large world companies have built capacities of tourist facilities with direct investments either through privatization, partnership, franchise, etc., in this case it's important that serious enterprises-investors know and understand the risk of action in other political and cultural environment from their domicile country, and they adapt to circumstances i.e. "game rules", and can extend their activities in these countries as an expansion, though they are present in other tourist countries of the region, or they want to take advantage of being the first in the countries that aim the tourism development. Foreign Direct Vertical Investments in fact appear in two forms, the first one is when the investor wants to make investment in other country, to manage to provide inputs for the process in the country of origin. And the second is when the investor wants to invest in a country, which he would exploit for the sale of his outputs. When it comes to investments in tourism, these forms are also applicable, that is, we have investors from different areas that invest in transport, sport and recreation, parking lots for yachts, etc. In both modes of foreign direct investments a question is made that why an investor would get into trouble and would like to spend in the capacity building in a foreign country? Certainly, each investor has his own specific arguments that make him give priority to a country. However, in general, there are two answers to this question and the first is the strategic behavior argument, while the second falls on that of access to non-perfect markets. Strategic behavior argument has to do with the case when investors, entering in new markets, take advantage of being the first, in order to be noticed in the future "game rule". The entry in non-perfect markets is a way which is preferred for those that want to put in their "know-how' reaching advantage and generating benefits, but also providing sustainability in that market investing in strategic tourist places.

\section{Conclusion}

Having done analyses in this paper we proved the existence of the causality and relationship between development of the tourism and involvement of International business especially through attracting Foreign Direct Investment. The country that has resources for development of tourism as Kosovo, and intention to develop a tourism sector through inflows of FDI will have to promote internationally the offer and attractions, there is a relationship between tourism related FDI and growth of incoming tourism. Regarding tourism development, it should be given an importance and priority in relation to other economic branches, taking into account its impact on other supporting branches of tourism, and more harmonized regional development, as well as the employment of active population. The inclusion in the international tourism market would be easier with attraction of foreign investments, overcoming of the tense political situation in the region, increasing of interstate communication, as well as, direct involvement of the EU with its projects for the stabilization and creation of 
preconditions for potential integration (IPA) of the region into the EU in the future. This expectation of the assistance from abroad doesn't mean that the country shouldn't be prepared intensively, starting from embracing of international and European norms and standards in tourism, trying to valorize its position and heritage, as a comparative advantage. The government has to implement the best practices in support of Investors interested for involvement in tourism sector by launching policies that stimulates them financially(taxes, relieves), while touristic organizations should be helped through different policies in promotion(international touristic fairs, web pages), and through incentives of their projects. The country should look up to good examples in the region and beyond with foreign investments and education of human resources (tourist workers), as key factor in tourism development, employment increase, and growth of social wellbeing in general. Under current circumstances in the region and beyond, the role of national institutions, as a locomotive, determines the fate of tourism development success in a country.

\section{References}

Ahmad Jafari Samimi, Somaye Sadeghi, and Soraya Sadeghi: "The Relationship between Foreign Direct Investment and Tourism Development: Evidence from Developing Countries “, Institutions and Economies, Vol. 5, No. 2, July 2013, pp. 59-68

Banka qendrore e Kosovës, Raporti Vjetor 2012, http://www.bqk-kos.org/repository/docs/2013/BQK-RV-2012.pdf

Daniels D. John, Radebaugh H. Lee and Daniel P. Sulivan, (20040, "International Business-environments and Operations", Pearsons, Prentice Hall, New Jersey.

Enti i Statistikave të Kosoves ,Statistikat e Hotelieris TM3 2013, TM3 2014

http://esk.rks-gov.net/publikimet/cat_view/81-hoteleria

http://ask.rks-gov.net/hoteleria/publikimet/doc_details/1184-statistikat-e-hotelerisaeuml-tm32014

Ebner,D. \& Baumgartner,R.J. 2006. The relationship between Sustainable Development and Corporate Social Responsibility. www.crrconference.org

Fatos Ukaj, Fetije Ukaj, "Characteristics of Marketing and Investment with Special Emphasis in Tourism", "Journal of Environmental Management and Tourism" JEMT; Association of Sustainable Education, Research and Science (ASERS) Romania, Biannually Journal, Volume II Issue 2(4) Winter 2011. ISSN 2068-7729. p 261-267. http://www.asers.eulasers_ files/jemt/JEMT\%20Volume\%20II\%20Issue\%202_4_\%20Winter \%202011_short.pdf

GDWH, What is Foreign Direct Investment, Horizontal and Vertical, 11 Januar 2011.http://guidewhois.com/2011/01/what-is-foreigndirect-investment-horizontal-and-verticall

Kukaj Halil(2014), "Biznesi Ndërkombëtar", Kolegji Fama, Prishtinë.

Llaci Shyqyri(2006), "Manaxhimi", Tiranë,

OECD Fact book 2013, Economic, Environmental and Social Statistics, Foreign Direct Investment. ISSN :1814-7364 (online), 09 January 2013, http://www.oecd-library.org/sites/factbook-2013 en/04/02/01/index.html?itemld=/content/chapter/factbook-201334-en

Report of the World Commission on Environment and Development, The United Nations Conference on Environment and Development, Having met at Rio de Janeiro from 3 to 14 June 1992, http://www.un-documents.net/rio-dec.htm

Sanford, D.M. and H. Dong (2000), "Investment in Familiar Territory: Tourism and New Foreign Direct Investment," Tourism Economics, 6 (3), pp. 205-19.

Sinclair, M.T. and Stabler, M. (2002) "The Economics of Tourism", London: Routledge.

Tisdell, C.and J. Wen (1991), "Investment in China's Tourism Industry: its Scale, Nature, and Policy Issues," China Economic Review, 2(2), pp. 175-93.

UNWTO Tourism Highlights 2013, http://dtxtq4w60xqpw.cloudfront.net/sites/all/files/pdf/unwto_highlights13_en_hr.pdf

Winston More. and Roland Craigwell: "Foreign direct Investment and Tourism in SIDS: evidence from causality tests", MPRA paper nr: 33438, posted 11 February 2011.

World Commission on Environment and Development. "Our Common Future, Chapter 2: Towards Sustainable Development " Report of the World Commission on Environment and Development, A 42/427, Geneva, Switzerland, June 1987.http://www.un-documents. net/ocf-02.htm; http://www.un-documents.net/wced-ocf.htm

WTO(World Tourism Organisation) http://www.unwto.org/facts/eng/vision.htm 